\title{
CHEMICAL AND BIOLOGICAL ASSESSMENT OF CHRYSICHTHYS FURCATUS FROM RIVER NIGER AT CABLE-POINT, ASABA
}

\author{
OLELE, N.F., NWACHI, O. F. AND OSHEMUGHENM, O. F. \\ Fisheries Department, Delta State University, Abraka, Asaba Campus, Nigeria.
}

Copyright 2010, Fisheries Society of Nigeria.

This paper was prepared for presentation at the $25^{\text {th }}$ Annual International Conference and Exhibition in Administrative Staff College of Nigeria (ASCON), Topo-Badagry, Lagos, Nigeria, $25^{\text {th }}-29^{\text {th }}$ October, 2010

This paper was selected for presentation by an FISON Program Committee following review of information contained in an abstract submitted by the author(s). Contents of the paper, as presented, have not been reviewed by the Fisheries Society of Nigeria and are subject to correction by the author(s). The material Fis malection Fisheries Society of Nigeria, its officers, or members. Papers presented at FISON meetings are subject to publication review by Editorial Committees of the Fisheries Society of Nigenia. Electronic reproduction, distribution, or storage of any part of this paper for commercial purposes without the written consent of the Fisheries Society of Nigeria is prohibited. Permission to reproduce in print is restricted to an abstract of not more than 300 words; illustrations may not be copied. The abstract must contain conspicuous acknowledgement of where and by whom the paper was presented. Write Librarian, Fisheries Society of Nigeria (FISON), P. O. Box 2607 Apapa, Lagos.

\section{ABSTRACT}

Bacteria flora predominates the skin of freshly caught fish, and will invade the tissue of the fish immediately after catch. Two preservative methods (cold smoking and freezing) were used to store eighteen specimens of Chrysichthys furcatus harvested from River Niger at Cable-point, Asaba. Two specimens were randomly selected every day from the cold smoked specimens and on weekly basis from the frozen specimens for physically, chemically and biologically examination for bacteria causing spoilage. Five bacteria isolates: Salmonella spp, Vibrio cholera, Escherichia coli, Staphylococcus aureus and Proteus vulgaris, were identified. Physical observation of the cold smoked fish after 24 hours showed the production of gas, off-odor, off flavour and slime formation. The colony forming units (CFU) of bacteria isolated from the fish immediately after harvest was $116 \times 10^{9}$ $\mathrm{cfu} / \mathrm{g}$. It increased to $268 \times 10^{9} \mathrm{cfu} / \mathrm{g}$ after 4 days of preservation, and to $64 \times 10^{9}$ cfu/g after four weeks of preservation. The Chi square $\left(x^{2}\right)$ analysis revealed that there was a significant difference between the bacteria load of frozen and cold smoked specimens. Free fatty acid value immediately after harvest was $0.90 \%$. It increased to $2.24 \%$ after four weeks in the freezer and $2.35 \%$ after four days of cold smoked storage. The Total Volatile Nitrogen profile at harvest time was 15.3 mgN/100g. It increased to $35.2 \mathrm{mgN} / 100 \mathrm{~g}$ after four days, (for the cold smoked specimens) and $26.3 \mathrm{mgN} / 100 \mathrm{~g}$ (for the frozen specimens) after four weeks. The peroxide and hydrogen ion concentrations followed the same increasing trend. The study revealed that freezer preservation was better than the cold smoked one. This is because bacteria proliferation was reduced and or halted in the frozen specimens, whereas it encouraged rapid bacteria growth in the cold smoked fish. The production of total volatile nitrogen (TVN), free fatty acid (FFA), peroxide value $(P V)$ and hydrogen ion concentration $(\mathrm{pH})$ was higher in the cold smoked specimens than in frozen ones, hence the cold smoked specimen exhibited shorter shelf life than their frozen specimens.

Key Words: Cold smoking, freezing, bacteria load, preservation, Chrysichthys furcatus and shelf life

\section{INTRODUCTION}

In Nigeria, the practice of holding harvested fish for long periods between catching and landing in open canoes without any form of preservation is worrisome. This action often results in quality changes as well as contamination of the fish by bacteria from the holding materials (Odoli, 2006). This unwholesome practice does not conform to simple hygiene, in keeping with the public health standards of fish consumption (Eyo, 2001).

Bacteria are ubiquitous, infesting the fish when the conditions are right and resulting in losses to fish mongers and consumers (Abdouchi, 1991). Fish 
spoilage has been the result of series of complicated changes that makes it unfit for human consumption. Fishermen lose income when fishes are not adequately preserved (Clucas, 1985 and Eyo 2001). To manage and overcome fish spoilage, preservation which is a branch of manufacturing has been used to transform raw fish into nutritious and safe products for human consumption (Stephanie and Martha, 2007).

The present study identified the bacteria causing spoilage in frozen and cold smoked specimens of Chrysichthys furcatus. It investigated the chemical changes taking place in cold smoked and frozen specimens. Results of biological and chemical test, in addition to physical observations were used to determine the shelf life of the specimens of study.

\section{OBJECTIVE OF STUDY:}

-the study investigated the influence of temperature abuse on the shelf life of Chrysichthys furcatus,

-identified which of the two preservative methods better extends the shelf life of the specimens,

-to note changes in PVC, FFA, PV and Ph.D

-ascertain if differences existed in the bacteria load/count of cold-smoked and frozen specimens

\section{SIGNIFICANCE OF STUDY:}

The need to increase fish consumption when proper preservative methods are used for newly harvested products is reechoed. This is in keeping with the need to improve fisheries contribution to the national economy through employment creation, foreign exchange earnings and food security support

\section{MATERIALS AND METHODS}

Eighteen specimens of Chrysichthys furcatus were purchased from the bank of the River Niger at Cable-point, Asaba, Delta State, Nigeria. Two specimens were randomly selected and examined immediately after catch to ascertain their organoleptic status, bacteria loads and chemical qualities of the fish. Out of the remaining sixteen specimens eight were cold smoked with $30 \%$ of moisture retained and stored on sterile table covered with heat treated wire gauze. A pair of the specimens were randomly withdrawn and examined every 24 hours for bacteria isolates and chemical changes of the fish. The other set of eight specimens were preserved in the deep freezer at a temperature of $-4^{\mathrm{O}} \mathrm{C}$. A pair of specimen from the deep freezer were randomly picked and observed weekly for one month as stated earlier (Brock et al, 1984 and Clucas, 1985). Processed specimens from both preservative methods were tested for total aerobic bacteria count according to Eyo, (2001). Suspicious bacteria colonies were identified on the basis of colonial morphology, cultural appearance and conventional biochemical tests according to the American Public Health Association (APHA) and Food and Drug Administration (FDA) isolation methods (APHA 1977; Brock et al 1984 and Lyhs et al. 2002).

Physical assessment using characteristic features of skin color, odor, texture, appearance and rigidity of fillets was carried out on cold smoked specimens. Thereafter, chemical and biological assessments were conducted on the cold smoked and frozen specimens according to (Abdalla, 2000; Olafsdottir and Fleurence, 1997). For chemical assessment, twenty grams of the frozen and cold smoked fish specimens were taken separately and homogenized in 250 $\mathrm{ml}$ of $0.1 \%(\mathrm{~W} / \mathrm{V})$ peptone water before a tenfold serial dilution was prepared (Odoli, 2006). The most probable number (MPN) was used for counting bacteria isolates at the Fisheries Laboratory located in Delta State University, Asaba Campus. MacConkey and Blood agar were used for the culture of bacteria isolates. Chemical changes: in $\mathrm{pH}$, total volatile nitrogen (TVN), peroxide value (PV) and free fatty acid (FFA) of cold smoked and frozen fish 
specimens were determined at the Nigeria Institute for Oil Palm Research (NIFOR) in Edo State. The statistical techniques used were chi-square $\left(x^{2}\right)$ and t-test analysis.

\section{RESULTS}

The colony forming units of bacteria $\left(\times 10^{9} \mathrm{cfu} / \mathrm{g}\right)$ isolated from the freshly caught specimens together with those identified from the processed specimens using both preservative methods are shown in table 1. The table revealed that five bacteria types (Salmonella spp, Vibrio cholera, Escherichia coli, Staphylococcus aureus and Proteus vulgaris) were isolated from the specimens. Escherichia coli recorded the highest number $\left(55 \times 10^{9} \mathrm{cfu} / \mathrm{g}\right)$ of bacteria; while the least was recorded for Salmonella $\left.\quad \begin{array}{lllll}\text { spp } & (8 & X & 10^{9} & \text { cfu/g }\end{array}\right)$ immediately after fish harvest. In week one, Vibrio cholera recorded the highest number $\left(33 \times 10^{9} \mathrm{cfu} / \mathrm{g}\right)$ in the frozen specimens while Staphylococcus aureus recorded the least value $\left(5 \times 10^{9} \mathrm{cfu} / \mathrm{g}\right)$. Proteus vulgaris recorded the highest bacteria $\left(71 \times 10^{9} \mathrm{cfu} / \mathrm{g}\right)$ isolate from the cold smoked specimens after four days. This bacterium was not isolated from the frozen specimen all through the study period. Generally, the bacteria isolates from the cold smoked specimens kept increasing by the day, whereas those isolated from the frozen specimens were on the decrease. 
Table 1: Colony forming units of bacteria ( $\mathrm{cfu} \times 10^{9} \mathrm{cfu} / \mathrm{g}$ ) identified using both preservative methods.

\section{Bacteria isolates Preservative methods and total count of colony forming bacteria $x \mathbf{1 0}^{9}$}

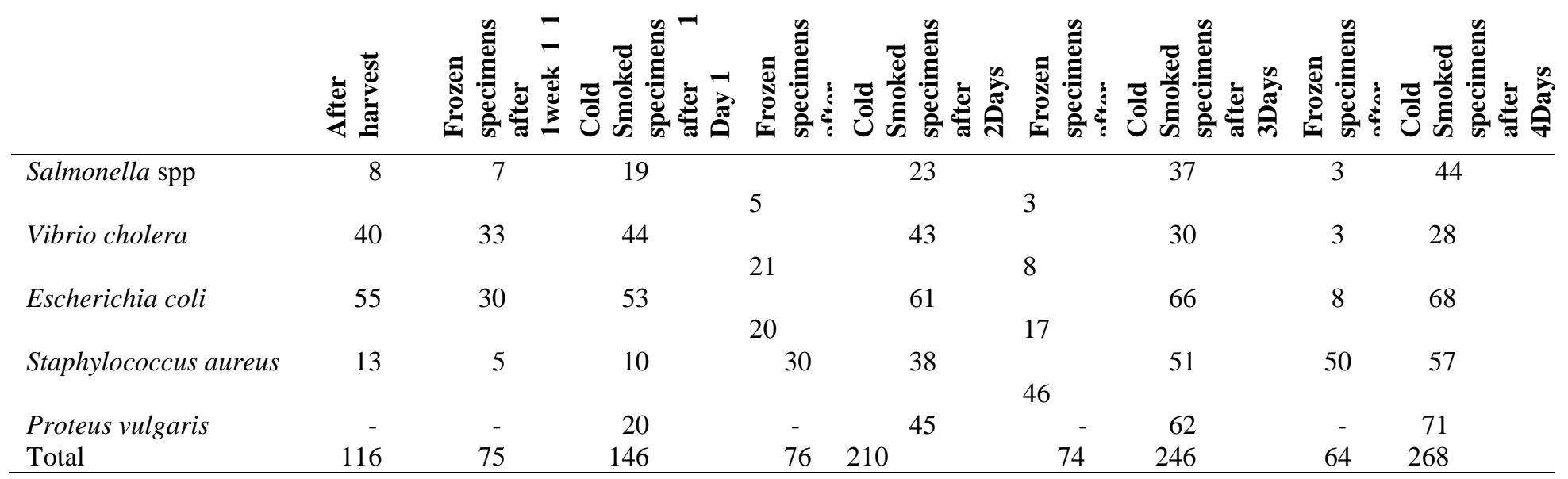

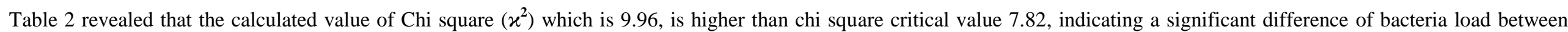
frozen and cold smoked specimens.

Table 2: Chi-square analysis of bacteria count from frozen and cold smoked specimen of Chrysichthys furcatus.

\begin{tabular}{|c|c|c|c|c|c|}
\hline \multirow[b]{2}{*}{$\begin{array}{l}\text { Time: } \\
\text { weeks/days }\end{array}$} & \multicolumn{3}{|c|}{$\begin{array}{l}\text { Bacteria count/wk } \\
\text { preservative methods }\end{array}$} & \multicolumn{2}{|c|}{ Chi-square analysis } \\
\hline & Frozen fish & Cold Smoked fish & Total & $x^{2}$ calculated & $x^{2}$ critical \\
\hline 1 & $5(3.60)$ & $30(31.4)$ & $35(35.0)$ & 9.96 & 7.82 \\
\hline 2 & $30(34.5)$ & $300(295.9)$ & $330(330.0)$ & & \\
\hline 3 & $80(101.4)$ & $900(878.6)$ & $980(980.0)$ & & \\
\hline 4 & $200(175.9)$ & $1500(1524.1)$ & $1700(1700.0)$ & & \\
\hline Total & 315 & 2730 & 3045 & & \\
\hline
\end{tabular}

$\mathrm{DF}=17$, level of significant $=0.05$

Table 3 revealed that the values for free fatty acid (FFA), total volatile nitrogen (TVN), peroxide value (PV) and hydrogen ion concentration ( $\mathrm{pH}$ ) analysed from the specimens increased well above the values observed immediately after fish harvest and from week 1 to week 4 when freezing and cold smoking preservations were used. The values derived from the cold smoked specimens were higher than those derived from the frozen specimens at the end of the preservation. 


\begin{tabular}{|c|c|c|c|c|c|}
\hline \multirow[t]{2}{*}{ TIME IN DAYS/ WEEKS } & \multirow{2}{*}{$\begin{array}{l}\text { METHODS OF } \\
\text { PRESERVATION }\end{array}$} & \multicolumn{4}{|c|}{ PROXIMATE ANALYSIS OF FISH SPECIMENS } \\
\hline & & FFA $(\%)$ & TVN (mgN/100g) & $\mathrm{PV}(\mathrm{MEq} / \mathrm{Kg}$ & $\mathrm{pH}$ \\
\hline AFTER HARVEST & $\begin{array}{l}\text { FISH FROM THE } \\
\text { RIVER }\end{array}$ & 0.90 & 15.3 & 3.7 & 7.9 \\
\hline End of Day 1 & COLD SMOKE & 1.42 & 27.1 & 10.2 & 5.2 \\
\hline End of Week 1 & FROZEN & 1.20 & 19.2 & 4.1 & 4.8 \\
\hline End of Day 2 & COLD SMOKE & 1.73 & 30.2 & 11.3 & 5.25 \\
\hline End of Week 2 & FROZEN & 1.88 & 24.1 & 7.2 & 4.9 \\
\hline End of Day 3 & COLD SMOKE & 2.04 & 32.2 & 13.7 & 5.30 \\
\hline End of Week 3 & FROZEN & 2.00 & 25.4 & 8.1 & 5.10 \\
\hline End of Day 4 & COLD SMOKE & 2.35 & 35.2 & 14.0 & 5.50 \\
\hline End of Week 4 & FROZEN & 2.24 & 26.3 & 8.9 & 5.30 \\
\hline
\end{tabular}

Table 3: Proximate analysis of fish samples during the period of study

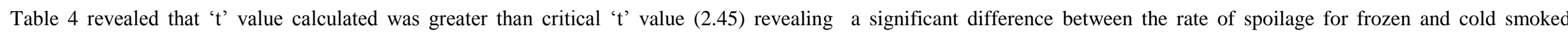
specimens. The cold smoked specimens exhibited greater and faster spoilage indices than the frozen specimens.

Table 4: shows the ' $\mathrm{t}$ ' values for TVN, PV, $\mathrm{pH}$ and FFA analysed from frozen and cold smoked fish specimens.

\begin{tabular}{|c|c|c|c|c|c|c|c|c|c|c|c|c|c|c|c|c|}
\hline \multirow{2}{*}{$\begin{array}{l}\text { Methods of } \\
\text { preservation }\end{array}$} & \multicolumn{4}{|l|}{ TVN } & \multicolumn{4}{|l|}{$\mathrm{pH}$} & \multicolumn{4}{|l|}{ PV } & \multicolumn{4}{|l|}{ FFA } \\
\hline & $\mathrm{X}$ & SD & $\begin{array}{l}\text { Mean } \\
\text { Diff }\end{array}$ & $\begin{array}{l}\mathrm{t}- \\
\text { value }\end{array}$ & $X$ & SD & $\begin{array}{l}\text { Mean } \\
\text { Diff }\end{array}$ & $\begin{array}{l}\mathrm{t}- \\
\text { value }\end{array}$ & $\mathrm{X}$ & SD & $\begin{array}{l}\text { Mean } \\
\text { Diff }\end{array}$ & $\begin{array}{l}\mathrm{t}- \\
\text { value }\end{array}$ & $\mathrm{X}$ & SD & $\begin{array}{l}\text { Mean } \\
\text { Diff }\end{array}$ & $\begin{array}{l}\mathrm{t}- \\
\text { value }\end{array}$ \\
\hline Frozen & 23.8 & 2.57 & 7.4 & 4.63 & 5.03 & 0.19 & 0.28 & 3.26 & 7.0 & 1.82 & 5.1 & 5.26 & 1.83 & 0.38 & 0.1 & 3.29 \\
\hline Cold Smoked & 31.2 & 2.97 & & & 5.31 & 0.09 & & & 12.2 & 1.54 & & & 1.89 & 0.35 & & \\
\hline
\end{tabular}


The values observed following the t- test analysis for Total Volatile Nitrogen (4.63), Hydrogen - ion Concentration (0.28) and Peroxide Value (5.26) are presented in Table 4. The observed $t$ - values were greater than their critical t-values (2.45), except for Hydrogen - ion Concentration whose value was less than the critical value of (0.28). It can therefore be concluded that there is a significant difference between the biochemical derivatives of frozen and cold smoked specimens of Chrysichthys furcatus. The physical assessment carried out for the cold smoked specimen by the taste panellists revealed greater spoilage outcomes than those observed for the frozen specimens. This implies that cold smoked specimens spoilt at a faster rate compared to the frozen specimens.

\section{DISCUSSION}

The prevalence of bacteria isolates in number and kind/types between the results of the present and past researchers agrees with those in literature (Truelstrup Hansen et al 1998, Eyo (2001, Lyhs, et al. 2002, Olokor et al 2007).

Difficulties using total counts of bacteria was reported, Lyhs, et al (2002). They opined that the initial count of bacteria in freshly caught fish was variable, whereas their systematic increase at temperatures between $0{ }^{\circ} \mathrm{C}$ and $20{ }^{\circ} \mathrm{C}$ occurred under irregular temperature storage conditions. It was also reported that there is no correlation between total count of bacteria and spoilage because not all bacteria results in spoilage (Odoli, 2006). Again there is no clear link between the organoleptic characteristic in spoilage when specific bacteria spoilage organisms are present (Olokor et al., 2007).

The result of the present study revealed that E. coli and Salmonella species were not identified in the cold smoked specimens. However, Staphylococcus species was present in salted cold smoked fish due to their survival during salting and smoking processes. This observation is similar to those reported (Lyhs, et al. 2002) and portends risk for Staphylococcus species infection and intoxication in humans.

The rejection point for the colony forming unit of bacteria was $10^{7}-10^{8} \mathrm{cfu}$ $\mathrm{g}^{-1}$ (Truelstrup Hansen et al 1998). This count was lower than that observed in the present study $268 \times 10^{9} \mathrm{cfu} / \mathrm{g}$ after 4 days of preservation; while that isolated from the frozen specimens after four weeks of preservation was $64 \times 10^{9} \mathrm{cfu} / \mathrm{g}$. The range in bacteria isolates from the frozen specimens was $\left(30-200 \quad\right.$ x $\left.10^{9} \quad \mathrm{cfu} / \mathrm{g}\right)$ whereas that encountered from the cold smoked specimen was (30- $1500 \times 10^{9}$ $\mathrm{cfu} / \mathrm{g}$ ). These numbers of bacteria isolates far exceeds the ideal for a healthy fish (Truelstrup Hansen et al 1998). Bacteria isolates differs in counts and types for various fish species for various studies.

The result of the present study has shown that there is a significant difference between the bacteria load of frozen and cold smoked specimens of Chrysichthys furcatus. The cold smoked specimens retained high moisture content after processing, which resulted to increased bacteria activities. This observation was supported by Eyo (2001). High moisture content promoted spoilage of the fish products.

The shelf- life of the frozen fish specimen in the present study is one week and two days, while that of the coldsmoked fish was twenty-four hours. This finding could be explained by the fact that when the fish was in the freezer, all bacteria activities become inactive, reduced or halted. According to Amos (1981) and Olokor et al (2007), when the temperature of a fish product is reduced, bacteria activities are retarded and spoilage processes halted. The frozen specimens exhibited longer shelf- life than the cold smoked ones. Increased moisture content of the cold smoked fish enhanced spoilage hence it promoted fish spoilage under cold smoking faster than all other traditional 
methods of preservation including freezing.

The difference in the rate of spoilage of the two groups of specimens could be attributed to factors such as methods of fish harvest, storage temperature, moisture content of smoked fish among others (Clucas, 1982).

The following values of free fatty acids (FFA $>1.5 \%$,), total volatile nitrogen (TVN > $20 \mathrm{MgN} / 100 \mathrm{~g}$ ), peroxide value $(\mathrm{PV}>5.0$ Milliequivalent/kilogram $(\mathrm{MEq} / \mathrm{Kg})$ and $\mathrm{pH}(<6.7)$ indicates the safe range for a healthy fish product and an ideal state of fish for consumption (Pearson, 1977 Olokor, et al 2007 ). According to Huss, 1988 the most significant factor influencing the texture of the fish and the degree of gaping/rupture of their connective tissues are changes in $\mathrm{pH}$ which drastically affects the properties of the connective tissues. Values of $\mathrm{pH}$ observed in the specimens of study after one week and two days (frozen specimens) and after 24 hours (cold- smoked specimen) revealed that spoilage had set in. Again, the values for TVN, PV and $\mathrm{pH}$ at the end of the first day revealed that spoilage had commenced in the cold smoked specimens.

The high prevalence of Lactic Acid Bacteria at a high level in the present study was expected since past studies showed that such bacteria species proliferates faster ( Duffes et al 1999; Martinsdöttir, 2002) under ambient conditions.

It is useful conducting microbiological and chemical analyses in parallel with sensory evaluation to have supporting information about the spoilage of fish (Chytiri, et al 2004)

\section{CONCLUSION}

Based on the findings of the present study, it was concluded that the frozen method of preserving Chrysichthys furcatus was comparatively better than the cold smoked method. This is because the frozen specimens exhibited longer shelflife than the cold smoked specimen.

\section{RECOMMENDATION}

In view of the present findings, the following recommendations are made.

1. Cold smoking alone should NOT be used as the only method of preserving fish because at best it adds flavour to the fish product, allowing a shorter shelf-life compare to other methods used in preserving fish.

2. In order to extend the shelf - life of a cold smoked fish, intermittent sun drying and or daily smoking could be done.

3. Moisture content less than $10 \%$ should be maintained in cold smoked fish, in order to reduce the growth of bacteria. Cold smoked fish can also be oven- dried, refrigerated or frozen, to inhibit the growth of some spoilage bacteria.

4. Where electricity is made constant, refrigeration of fish would remain the best method of fish preservation because it does not only keep the fish in a near fresh state, but also prevents the growth of bacteria.

\section{CONTRIBUTION TO KNOWLEDGE}

The result of the present study will serve as key factor in preventing post harvest losses, hence improving the overall freshness of fish landed and in return increase revenue to the fisher folk in general and to the Nigeria populace in particular.

\section{REFERENCE}

Abadouchi, L. (1991). Histamine food poison: An update FAO tech. new vol.ii, no.1, p3-5 \& 9 . 
Abdalla, M.T. (2000). Microbiology and biochemistry of Fessiekh fermentation. A thesis submitted in partial fulfilment of the requirement for the award of the degree M,Sc. in food microbiology, Faculty of Agriculture, University of khartoun.

APHA, (1977). Compendium of methods for the micrological examination of food, $3^{\text {rd }}$ edition.

Brock, T.D., Smith, D.W. and Madigan, M.T. (1984), Bacterial, Taxonomy and Identification. In Biology of Micro-organisms. $4^{\text {th }}$ Edition. Prentice Hall Inc. Englewood Cliffs, N.J. Pp 610 - 624.

Chytiri, S., Chouliara, I., Savvaidis, I. N. and Kontominas, M. G. (2004). Microbiology, chemical and sensory assessment of iced whole and filleted aquacultured rainbow trout. Food Microbology. 21: 157165.

Clucas I.J (1985). Fish handling, preservation and processing in the tropics, part 1. Tropical development and research institute, London. 141p

Eyo, A.A. (2001). Fish processing technology in the tropics. A textbook. $120 \mathrm{p}$

Huss, H. H. (1988). Fresh fish quality and quality changes. Rome. FAO/DANID. A training manual. FAO training series No. 29.
Lyhs, U., Korkeala, H. and Bjoőrkroth, J. (2001). Lactobacillus alimentarius: a specific spoilage organism in marinated herring. International Journal of food Microbiology. 64, 355-360.

Lyhs, U., Korkeala, H. and Bjoörkroth, J. (2002). Characterization of Lactic Acid Bacteria from spoiled, vacuum packed gravid rainbow trout using ribo typing. International Journal of Food Microbiology. 72: 147-153.

Martinsdőttir, E. (2002). Quality management of stored fish. In Bremner, H. A. ed. England: Woodhead Publishing Limited. Safety and quality issues in fish processing. Pp 360-378.

Odoli, C. O. (2006). The effect of temperature abuse at the beginning of storage on the quality and shelf life of fresh water arctic charr (Salvelinus alpinus). Fisheries Training Programme. Pp 1-46.

Olokor .J.C., J.A. Ihuahi, F.S. Omojowo, B.A. Falyi , E.O. Adelowo (2007). Practical Fisheries Technology, NIFFR.

Pearson, D. (1976). The chemical Analysis for foods.

Stephanie, T.D. and Martha, B.S. (2007). Food processing and preservation, Microsoft ® Encarta ® 2007. 